\section{Clinical and Histological Features of Multifocal Canalicular Adenomas of the Upper Lip}

Carla Silva Siqueira, Karin Sá Fernandes, Ana Paula Molina Vivas, Décio dos Santos Pinto Junior, Suzana Cantanhede Orsini Machado de Sousa
Department of Stomatology,

Oral Pathology, School of

Dentistry, USP - University of São

Paulo, São Paulo, SP, Brazil

Correspondence: Dra. Karin Sá Fernandes, Avenida Prof. Lineu Prestes, 2227, Cidade Universitária, 05508-900 São Paulo, SP, Brasil. Tel.: +55-11-3091-7912. e-mail: karinsf@gmail.com

\begin{abstract}
Canalicular adenoma (CA) is an uncommon benign salivary gland tumor that mostly occurs in the upper lip. Despite its benign nature, some patients may present multiple nodules and also microscopic growth that can be multifocal with foci of tumor within the adjacent gland. Microscopically, CA can be mistaken for a polymorphous low-grade adenocarcinoma (PLGA) or basal cell adenoma (BCA), and immunohistochemistry can be helpful in differentiating them. Two cases of canalicular adenoma showing tumor foci within the adjacent gland are described. Both cases occurred in the upper lip of white females aged 72 and 79 years. In addition to the histological multifocal aspect, one of the patients presented bi-lateral nodules. Histological examination of both lesions revealed interconnecting and branching canal-like structures composed by uniform columnar and sometimes cuboidal cells, partially encapsulated. Immunohistochemical analysis showed intense expression of cytokeratins (CK) 7, a weak reaction to CK14 and a negative reaction to vimentin. Upon the diagnosis of CA the lesions were excised. In conclusion, it is important to properly diagnose CA and differentiate its multifocal aspect from a malignant behavior.
\end{abstract}

Key Words: adenoma, histopathology, immunohistochemistry, upper lip.

\section{Introduction}

Canalicular adenoma (CA) is a benign salivary neoplasm that primarily affects minor salivary glands (1). It is a rare entity, representing less than $1 \%$ of salivary gland tumors (2). Previously, along with basal cell adenoma, CA was classified as a monomorphic adenoma. In 1992 they were separated into two different lesions by the World Health Organization classification of salivary gland neoplasms $(3,4)$.

CA affects mostly elderly women at a mean age of 60 years (5). It has a predilection for the upper lip, which accounts for $70 \%$ of all cases (3), followed by buccal mucosa and palate $(1,3)$. Usually, it appears as a solitary nodule; the occurrence of multiple CAs is an uncommon clinical finding (1).

Histopathologically, CA is composed by columnar or cuboidal monomorphic epithelial cells arranged in bilayered strands and ducts in a loose and relatively fibrous stroma (6). The presence of microscopic tumor island foci adjacent to the main lesion, within the capsular tissue, or in the normal salivary gland tissue determines the multifocal CA (5-8). Frequently, diagnosis is achieved by histopathology and examination of the immunohistochemical profile. The histological features of CA can mimic those of polymorphous low-grade adenocarcinoma (PLGA) and basal cell adenoma (BCA) $(3,7,9)$.

In view of the rarity of the lesion, two cases of $C A$ are reported, one bilateral and multifocal and the other a solitary lesion with multifocal histologic growth. In both cases lesions were detected in the upper lip of elderly women.

\section{Case Report \\ Case 1}

A 72-year-old White female was admitted to our Department of Stomatology with a chief complaint of a small nodule in the upper lip with 1-year duration. The lesion was asymptomatic, and the patient's medical history was irrelevant. The patient was not on medication and had a history of tobacco use.

At the extraoral examination, the patient presented facial symmetry and normal color of the skin with no associated lymphadenopathy. The intraoral examination revealed that the labial mucosa was intact, with normal color and shape and no signs of lesion. However, on palpation, a 5-mm submucous smooth and rubbery in consistency nodule was noted, located on the left side (Fig. 1). Pain and bleeding were absent. The differential diagnosis included mucocele and the hypertrophic salivary gland. An excisional biopsy was performed under local anesthesia. The material was submitted to histopathological analysis. During the procedure, there was no difficulty in separating the lesion from the surrounding tissues.

Histopathological examination revealed a benign, partially encapsulated epithelial neoplasm and smaller 
multifocal growths (Fig. 2A). The neoplasm was composed of columnar cells that formed canal-like ductal structures. Individually the cells were eosinophilic with regular nuclei and no pleomorphism (Fig. 2B). Immunohistochemical reactions showed intense expression of cytokeratin (CK) 7, a weak reaction to $\mathrm{CK} 14$ and a negative reaction to vimentin.

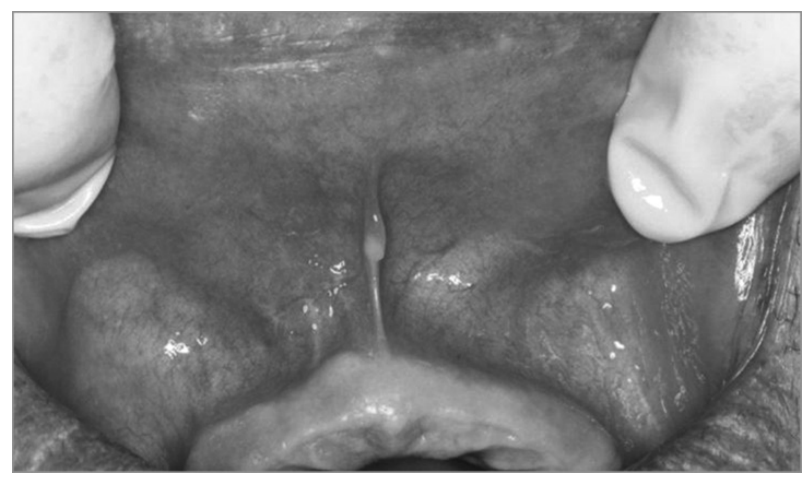

Figure 1. Clinical aspect of the lesion as a submucous nodule in the labial mucosa.
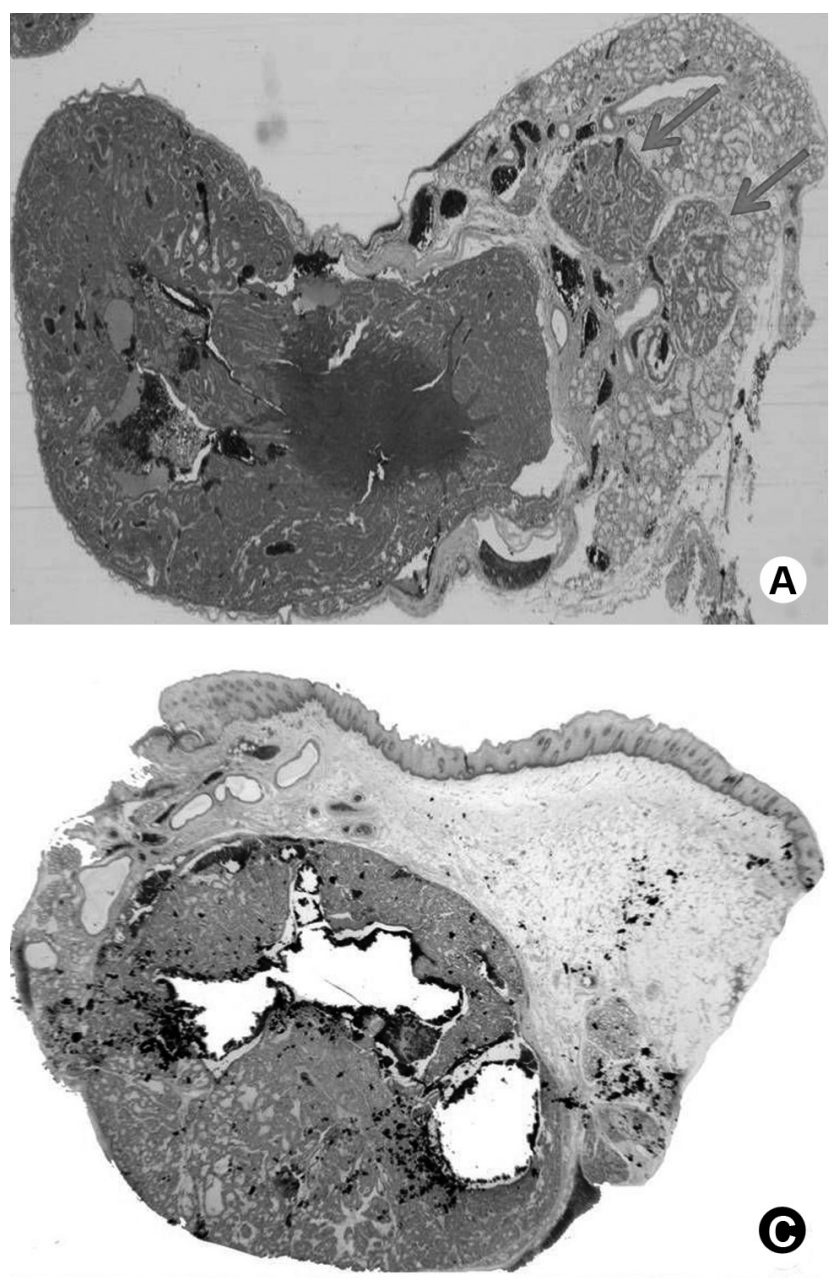

During the postoperative examination, the patient complained of a similar nodule on the right side of the upper lip, but smaller than the first. The lesion was identical both extra- and intra-orally to the first one. It was also removed under local anesthesia with a clinical hypothesis of CA. Microscopically, ductal structures of the minor salivary gland within a vascular connective tissue stroma were seen. In some areas, dilated ducts and incipient foci of CA were present characterized by columnar cells with regular nuclei and eosinophilic cytoplasm. The diagnosis of CA was confirmed.

One month after her first visit, the patient remained asymptomatic with no evidence of new lesions or recurrence. She was advised to return every six months for follow-up appointments due to the tumor's multifocal nature and potential for relapses.

\section{Case 2}

A 79-year-old White female was admitted to our Department of Stomatology complaining of a small nodule in the upper lip with duration of 5 months. The lesion
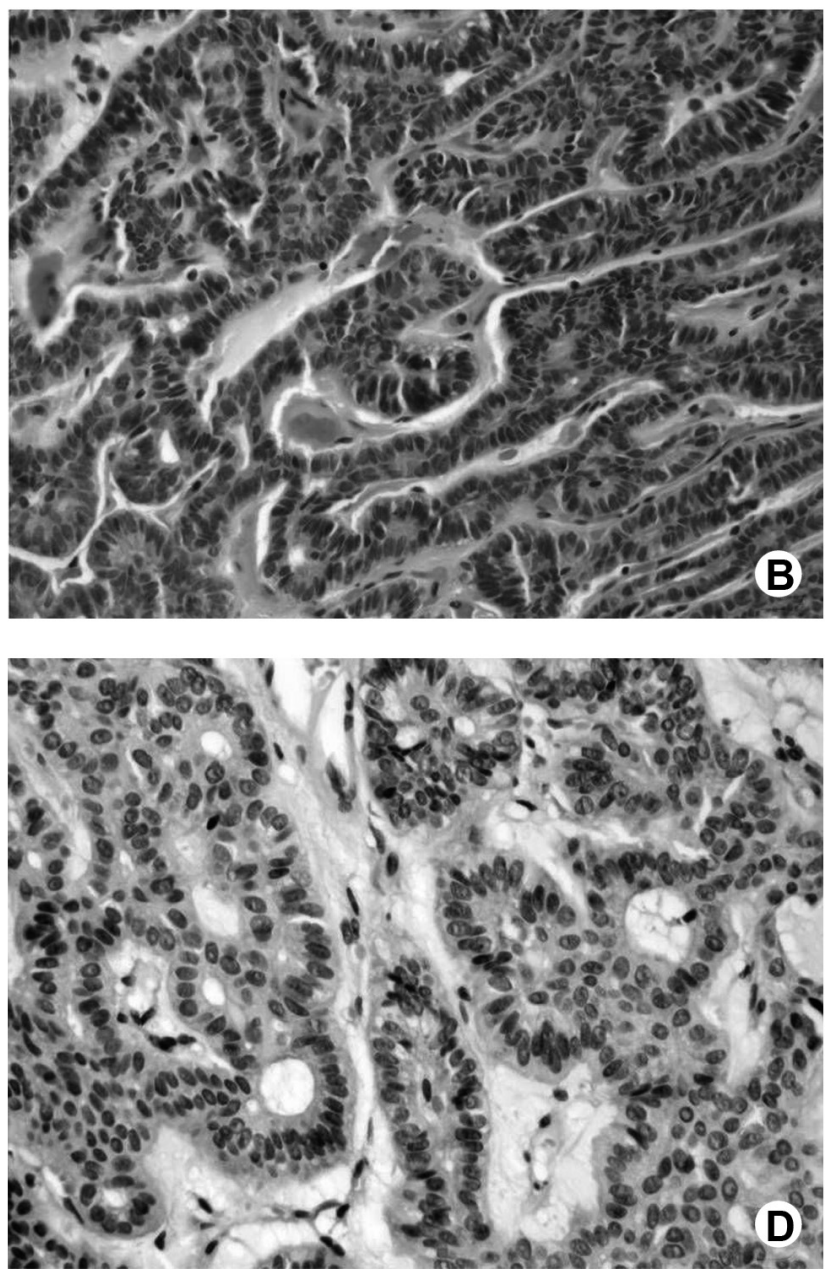

Figure 2. Histopathological examination. Case 1 (A,B). Case 2 (C,D). 
was asymptomatic and the patient's medical history was irrelevant. She was not on medication and had a history of tobacco use.

At the extraoral examination, she presented facial symmetry and normal color of the skin with no associated lymphadenopathy. Intraoral examination revealed a 12-mm painless, firm nodular mass with defined borders, covered by normal mucosa with no bleeding. Differential clinical diagnoses included pleomorphic adenoma and malignant neoplasm of salivary glands. An incisional biopsy was performed, and the specimen was sent to histopathological examination.

Histopathological examination revealed a benign, partially encapsulated epithelial neoplasm (Fig. 2C) and
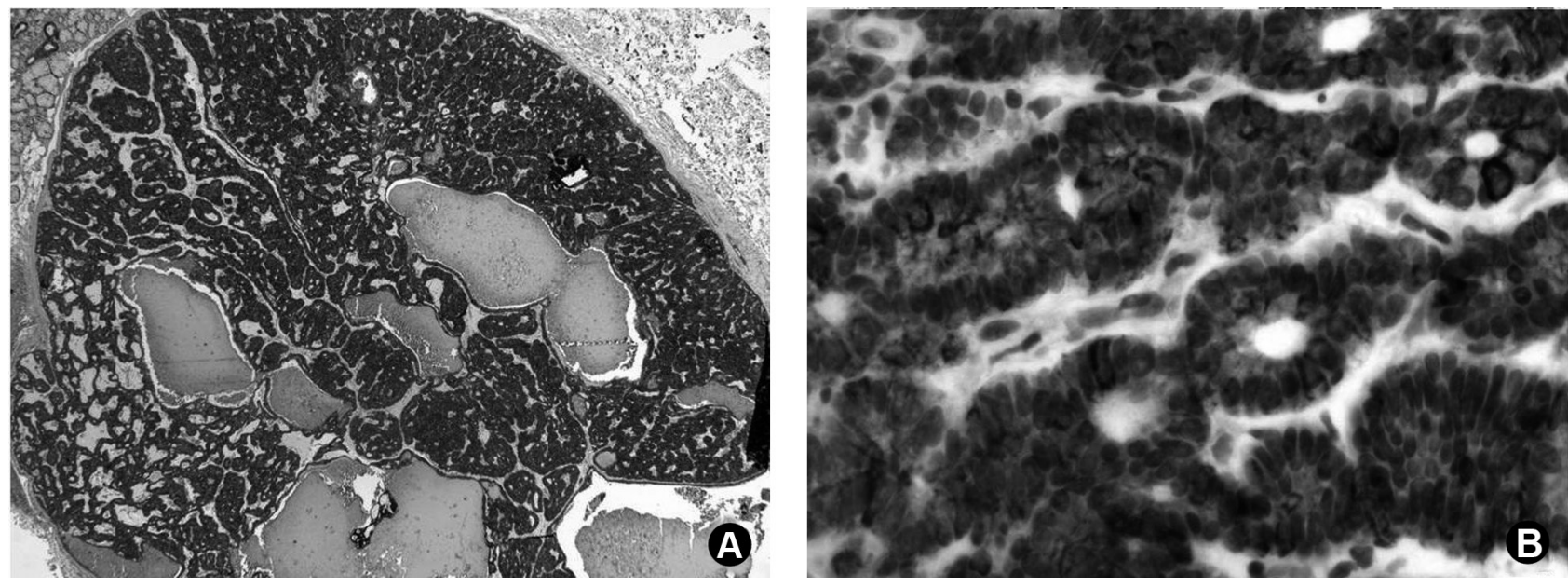

Figure 3. Immunohistochemical staining of CK 7 (Case 2).

Table 1. Clinical and microscopic features of multifocal canalicular adenomas and recurrence on minor salivary glands

\begin{tabular}{|c|c|c|c|c|c|c|}
\hline Case & Age & Gender & Location & Tumor characteristics & Clinical presentation & Author (year) \\
\hline 1 & 78 & $\mathrm{~F}$ & Upper lip & $\begin{array}{l}2 \text { nodules on the right side } \\
\text { and } 2 \text { lesions on the left side }\end{array}$ & Synchronous & $\begin{array}{l}\text { Mansueto et } \\
\text { al, } 2009\end{array}$ \\
\hline 2 & 76 & $\mathrm{~F}$ & Upper lip & $\begin{array}{l}2 \text { distinct masses on the } \\
\text { right and left side }\end{array}$ & Metachronous & Yoon et al., 2006 \\
\hline 3 & 26 & M & Parotid glands & $\begin{array}{l}\text { Lobulated masses in } \\
\text { both parotid glands }\end{array}$ & Synchronous & Liess et al., 2006 \\
\hline 4 & 68 & $\mathrm{~F}$ & Upper lip & 22 nodules & Synchronous & $\begin{array}{l}\text { Queiroz et } \\
\text { al., } 2004\end{array}$ \\
\hline 5 & 64 & M & $\begin{array}{l}\text { Upper lip and } \\
\text { buccal mucosa }\end{array}$ & 13 submucosal nodules & Synchronous & $\begin{array}{l}\text { Rousseau et } \\
\text { al., } 1999\end{array}$ \\
\hline 6 & 75 & $\mathrm{~F}$ & Buccal mucosa & $\begin{array}{l}2 \text { distinct masses in the left } \\
\text { cheek mucosa and the third } \\
\text { lesion appeared } 9 \text { months later }\end{array}$ & Metachronous & $\begin{array}{l}\text { Nelson et } \\
\text { al., } 1995\end{array}$ \\
\hline 7 & 59 & M & $\begin{array}{l}\text { Upper lip and } \\
\text { buccal mucosa }\end{array}$ & $\begin{array}{l}6 \text { lesions of the buccal mucosa and } \\
\text { one - the largest, in the upper lip; } \\
\text { next } 14 \text { new nodules confined to } \\
\text { the upper lip and buccal mucosa } \\
\text { were excised 1y and } 6 \text { months later }\end{array}$ & Metachronous & $\begin{array}{c}\text { Khullar et } \\
\text { al., } 1992\end{array}$ \\
\hline 8 & 57 & $\mathrm{~F}$ & Upper lip & 1 nodule & - & $\begin{array}{l}\text { Tyralik et } \\
\text { al., } 2013\end{array}$ \\
\hline \multirow[t]{2}{*}{9} & 72 & $\mathrm{~F}$ & Upper lip & $\begin{array}{l}1 \text { nodule on the right side and } \\
1 \text { nodule on the left side }\end{array}$ & Synchronous & \multirow[t]{2}{*}{ Present case } \\
\hline & 79 & $\mathrm{~F}$ & Upper lip & 1 nodule & - & \\
\hline
\end{tabular}

Table adapted from Tyralik et al. (2013). 
also multifocal microscopic growths adjacent to the larger one. The main lesion was composed by columnar cells forming canal-like ductal structures. Individual cells were eosinophilic with regular nuclei and did not show pleomorphism (Fig. 2D). Immunohistochemical reactions showed an intense expression of cytokeratin (CK) 7 (Figs. 3A and $3 \mathrm{~B}$ ), a weak reaction to $\mathrm{CK} 14$, and a negative reaction to vimentin. A diagnosis of $C A$ was established and the nodule was excised. Two months after her first visit, the patient remained asymptomatic with no evidence of recurrence.

\section{Discussion}

$\mathrm{CA}$ is a rare benign neoplasm arising mainly from minor salivary glands and rarely involving the major salivary glands (1). Clinically, it presents as a soft and loose nodule with non-ulcerated overlying mucosa. The lesion tends to be solitary, but sometimes shows multiple tumors or confluent masses of variable sizes. Those features are not exclusive to $C A$ and thus it can frequently be mistaken by other lesions, such as sialoliths or other benign salivary gland tumors. No hypothesis of malignant lesion was suggested because of the bland appearance, circumscribed, mobile and slow growth $(7,10)$.

The histopathological findings include columnar or cuboidal cells that form double strands or ducts in a loose stroma. The presence of tumor islands within the glandular tissue or within the fibrous capsule constitutes the multifocal pattern of CA. Rousseau et al. (5) described three distinct patterns of multifocal CAs: the clinically multifocal, the microscopically multifocal, and the multifocal recurrence (5). There are a few cases reported in the literature involving microscopically and clinically multifocal CAs (Table 1). However, in some articles it is difficult to assure whether they are referring to a histologic or clinical multifocality. Nevertheless, as in the reports published before 1992 CAs were classified as monomorphic adenomas or basal cell adenomas, and the majority of recent studies do not include the term multifocal in their diagnosis, it is difficult to determine the true rarity of the multifocal nature. In addition, clinically multifocal tumors are referred to as multiple adenomas, which can lead to underestimation of the true frequency of multifocal CAs.

In the above-described cases, one of the patients (Case 1) presented a bilateral lesion (clinically multifocal) on the upper lip and the other presented a solitary lesion. Histologically, both cases showed multifocal growth. However, in spite of the multifocal growth, neither of the cases presented an invasive behavior, as the growths were within the salivary glands. These aspects have been reported previously $(1,10)$. The lesions of the first patient were quite small, submucosal and difficult to visualize. The first one was seen only after the patient showed it and, the second lesion was even smaller, and could only be detected by a detailed inspection.

It is important to differentiate histologically CA from other salivary gland tumors, especially malignant tumors such as the PLGA. This neoplasm is characterized histologically by uniform nuclear features of the cells, diverse patterns of architecture and infiltrative growth besides neurotropism. When the predominant feature of the PLGA is the canalicular pattern of growth it can be easily taken as a CA. Sometimes only histological aspects are not enough to the distinction, especially if malignant aspects such as infiltrative growth are missing. In these cases, immunohistochemistry is necessary for the final diagnosis given that the different clinical behavior requires a different treatment and thus an accurate diagnosis is mandatory (9). Consistent with other studies $(4,10)$, the present cases also showed CK 7 positivity and the presence of CK 14 in groups of cells. The negativity to vimentin rules out the diagnosis of PLGA and basal cell adenoma. Vimentin has been widely employed as a marker for neoplastic myoepithelial cells, (14) but in the developing gland and in normal adult gland, myoephithelial cells do not express vimentin (3). Despite the multifocal histological growth, the tumor is never infiltrative as it only pushes the glandular tissue.

Another lesion that should also be included in the differential diagnosis is the basal cell adenoma (4). The primary distinguishing clinical features are the age of the affected patients, since CA usually occurs in patients over 50 years of age, and the lesion site, as BCA are found mainly in the major salivary glands, in contrast to CA $(6,7)$. Histologically and differently from CA, BCA has usually a tendency to present two cell types, with the formation of duct structures. Thus, even the solid type on immunohistochemistry reactions shows an expression of myoepithelial markers (smooth muscle actin, vimentin, and others) only in the peripheral columnar cells in palisade. Comparing the ultrastructural aspects, CA could have an excretory duct origin although an intercaled duct origin has also been indicated. On the other hand, the basal cell adenoma could originate from a myoepithelial or an intercalated duct lineage (3). Treatment of CA consists of a simple enucleation despite the multifocal growth. However, when this multifocal nature is observed, the patient must be kept under close supervision (6).

In conclusion, CA has an excellent prognosis after conservative surgical treatment but needs a longer followup because of this multifocal occurrence. Moreover, the immunohistochemical study is contributory in separating different entities.

\section{Resumo}

0 adenoma canalicular (AC) é uma rara neoplasia benigna de glândula 
salivar que ocorre com maior frequência em lábio superior. Apesar de sua natureza benigna, alguns pacientes podem apresentar múltiplos nódulos, além de apresentar microscopicamente um crescimento multifocal com focos de neoplasia na glândula adjacente. Microscopicamente, AC pode ser confundido com adenocarcinoma polimorfo de baixo grau ou adenoma de células basais, sendo a imunohistoquímica útil na diferenciação entre eles. Dois casos de AC com focos de neoplasia dentro da glândula são descritos. Ambos os casos ocorreram em lábio superior de dois individuos do sexo feminino com 72 e 79 anos de idade. Além do aspecto histológico multifocal, um dos pacientes apresentou nódulos bilaterais. A análise histológica dos dois casos revelou estruturas canaliculares interligadas, compostas por células colunares uniformes e cuboidais, parcialmente encapsuladas. A análise imunohistoquimica mostrou intensa marcação de citoqueratina (CK) 7, uma fraca expressão para CK14, e reação negativa para vmentina. Após o diagnóstico as lesões foram excisionadas. Conclusão: É importante o correto diagnóstico do AC e a diferenciação do aspecto multifocal de um comportamento maligno.

\section{References}

1. Yoon AJ, Beller DE, Woo VL, Pulse CL, Park A, Zegarelli DJ. Bilateral canalicular adenomas of the upper lip. Oral Surg Oral Med Oral Pathol Oral Radiol Endod 2006;102:341-343.

2. Liess BD, Lane RV, Frazier S, Zitsch RP, 3rd. Bilateral canalicular adenoma of the parotid gland. Arch Otolaryngol Head Neck Surg 2006;132:339-341.

3. Sousa SOM, Araújo NS, Correa L, Soubhia AMP, Araújo VC. Immunohistochemical aspects of basal cell adenoma and canalicular adenoma of salivary glands. Oral Oncol 2001;37:365-368.

4. Ferreiro JA. Tumours of the salivary glands. In: Barnes L, Eveson JW, Reichart P, Sidransky D. World Health Organization Classification of Tumours. Pathology \& Genetics. Head and Neck Tumours. International histological classification of tumors. IARC Press Lyon 2005.

5. Rousseau A, Mock D, Dover DG, Jordan RC. Multiple canalicular adenomas: a case report and review of the literature. Oral Surg Oral Med Oral Pathol Oral Radiol Endod 1999;87:346-350.

6. Nelson ZL, Newman L, Loukota RA, Williams DM. Bilateral multifocal canalicular adenomas of buccal minor salivary glands: a case report. Br J Oral Maxillofac Surg 1995;33:299-301.

7. Matsuzaka K, Murakami S, Shimono M, Inoue T. Canalicular adenoma arising in the upper lip: review of the pathological findings. Bull Tokyo Dent Coll 2004;45:229-233.

8. Daley TD. The canalicular adenoma: considerations on differential diagnosis and treatment. J Oral Maxillofac Surg 1984;42:728-730.

9. Furuse C, Tucci R, Sousa SOM, Carvalho YR, Araújo VC. Comparative Immunoprofile of Polymorphous Low-Grade Adenocarcinoma and Canalicular Adenoma. Ann Diagn Pathol 2003;7:278-280.

10. Mansueto G, Falleti J, De Cecio R, Papa F, De Rosa G. Synchronous bilateral multifocal canalicular adenoma: a case report of an unusual finding. Clin Exp Dermatol 2009;34:e587-e589.

11. Queiroz LM, da Silveira EJ, Silva Arruda M de L, Ramos CC. A rare salivary gland neoplasm: multiple canalicular adenoma: A case report. Auris Nasus Larynx 2004;31:189-193.

12. Khullar SM, Best PV. Adenomatosis of minor salivary glands. Report of a case. Oral Surg OralMed Oral Pathol 1992;74:783-787.

13. Tyralik D, Dzierwa-Gawron A, Ryś J. Canalicular adenoma of the upper lip. Metachronous (multifocal) canalicular adenoma of the upper lip: a case report of an unusual finding. Pol J Pathol 2013;64:71-74.

14. Cavalcante RB, Lopes FF, Ferreira AS, Freitas R de A, de Souza LB. Immunohistochemical expression of vimentin, calponin and HHF-35 in salivary gland tumors. Braz Dent J 2007;18:192-197.

Received May 23, 2013 Accepted August 16, 2013 